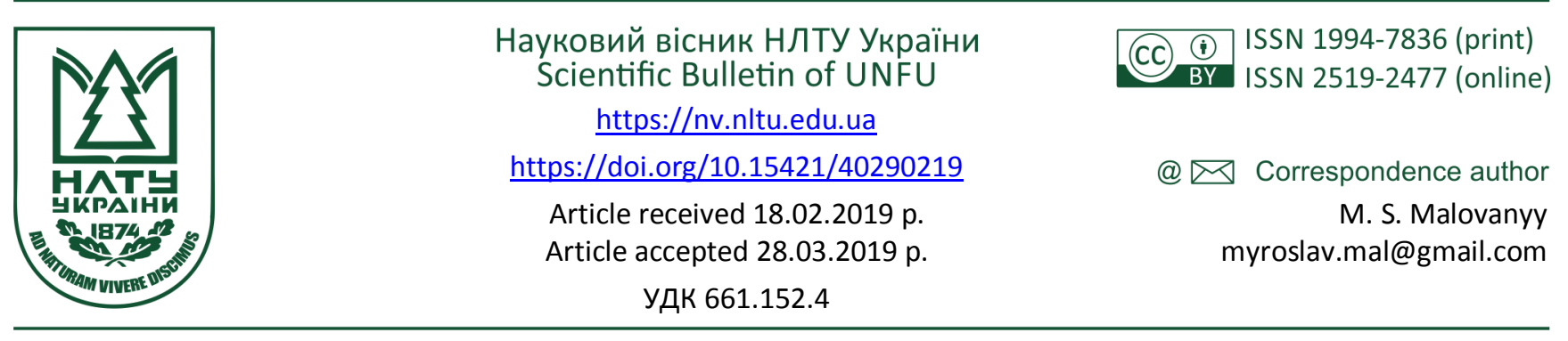

Л. Л. Гурець', Ю. Л. Цапко², М. С. Мальований , В. С. Вакал1

${ }^{1}$ Сумський державний університет, м. Суми, Украӥна ${ }^{2}$ Національний науковий центр "Інститут агрохімї та трунтознавства ім. О. Н. Соколовського", м. Харків, Украйна ${ }^{3}$ Національний університет "Львівська політехніка", м. Львів, Україна

\title{
ЕКСПЕРИМЕНТАЛЬНІ ДОСЛІДЖЕННЯ КІНЕТИКИ РОЗЧИНЕННЯ КАПСУЛЬОВАНИХ АЗОТНИХ ДОБРИВ
}

Визначено зменшення техногенного навантаження на довкілля при зниженні швидкості розчинення азотних мінеральних добрив шляхом капсулювання їх фосфатами. Встановлено, що включення до складу фосфатовмісного покриття сорбентів і гуматів дає змогу змінювати характеристики органо-мінеральних добрив. Проведено експериментальні дослідження 3 кінетики розчинення азотних добрив, капсульованих оболонками на основі вітчизняних фосфоритових концентратів, визначено втрати поживних елементів з гранул і оцінено вплив складників фосфатовмісної оболонки на міграцію у грунт водорозчинних форм кадмію і свинцю. У ході лабораторних досліджень показано, що застосування оболонки на основі амонізованого суперфосфату та порошкоподібного фосфат-глауконітового концентрату Ново-Амвросіївського родовища призводить до істотного зниження швидкості розчинення азотного складника капсульованої гранули. Встановлено, що на зв'язування важких металів у нерозчинні комплекси позитивно впливають інтенсивність зволоження і властивості модифікованих добрив. Визначено, що зниження кислотності грунтових комплексів при введенні до складу фосфатовмісної оболонки гуматів лужних металів зменшує вміст водорозчинних форм важких металів у орному шарі і підвищує екологічну безпеку сільськогосподарського виробництва.

Ключові слова: карбамід; амоніачна селітра; капсулювання; суперфосфат амонізований; фосфат-глауконітовий концентрат; важкі метали.

Вступ. У контексті євроінтеграції постає важливе для України питання забезпечення сталого розвитку усіх складових соціально-економічної системи держави. Сталий розвиток держави має забезпечувати підтримку високого і сталого рівня економічного зростання та зайнятості; ефективну охорону довкілля; бережливе використання природних ресурсів.

Одним із аспектів цього питання $є$ вирішення продовольчої проблеми, яке неможливе без застосування мінеральних добрив. Водночас неконтрольоване внесення добрив призводить до забруднення грунтів, погіршення якості сільськогосподарської продукції, завдає шкоди здоров'ю населення.

Підвищення рівня екологічної безпеки при застосуванні високих доз мінеральних добрив у сільськогосподарському виробництві $\epsilon$ невідкладним завданням сьогодення й досягається шляхом зниження потенційної загрози надходження у грунти значної кількості нітратів під час розчинення гранул азоту. Одним із напрямків виконання цієї умови $є$ оптимізація азотного

живлення в екосистемі грунт - рослина. При одночасному удобренні грунтів азотно-фосфатно-калійними (NPK) добривами поживні елементи туків мають різну швидкість розчинення, і тому з'являється можливість завдяки повільному розчиненню фосфатного складника уповільнити час надходження азоту у грунт. Це технічне рішення реалізується шляхом нанесення фосфатної або фосфатно-калійної захисної оболонки на гранулу азотного добрива. Водночас залучення як фосфатного складника оболонки добрива фосфат-глауконітового концентрату передбачає зниження кислотності грунту, а отже, зменшення рухомих форм важких металів у грунті й сільськогосподарській продукції. Розроблення такої композиції дає змогу сформулювати вимоги до складного NPK-добрива, яке за своїми властивостями буде екологічно безпечним та матиме високу агрохімічну ефективність.

Постановка проблеми. Інтенсивне сільськогосподарське виробництво на сьогодні неможливе без застосування значних доз мінеральних добрив хоча б для

Інформація про авторів:

Гурець Лариса Леонідівна, д-р техн. наук, доцент, кафедра прикладної екології. Email: Iarisagurets@gmail.com; https://orcid.org/0000-0002-2318-4223

Цапко Юрій Леонідович, д-р біол. наук, ст. наук. співробітник, завідувач лабораторії гідроморфних і кислих ґрунтів.

Email: tsapkoul@i.ua

Мальований Мирослав Степанович, д-р техн. наук, професор, завідувач кафедри екології та збалансованого природокористування. Email: myroslav.mal@gmail.com; https://orcid.org/0000-0002-3868-1070

Вакал Вікторія Сергіївна, здобувач, наук. співробітник, Науково-дослідний інститут мінеральних добрив і пігментів наукової частини. Email: vsvakal@gmail.com; https://orcid.org/0000-0003-2208-7162

Цитування за ДСту: Гурець Л. Л., Цапко Ю. Л., Мальований М. С., Вакал В. С. Експериментальні дослідження кінетики розчинення капсульованих азотних добрив. Науковий вісник НлтУ України. 2019, т. 29, № 2. С. 94-98

Citation APA: Gurets, L. L., Tsapko, Yu. L., Malovanyy, M. S., \& Vakal, V. S. (2019). Experimental studies of the kinetics of capsulated nitrogen fertilizers dissolution. Scientific Bulletin of UNFU, 29(2), 94-98. https://doi.org/10.15421/40290219 
часткової компенсації поживних речовин, що містяться у грунті і виносяться разом 3 урожаєм. При цьому швидке розчинення високих доз азотних добрив загрожує довкіллю значним надходженням нітратів, а фосфатних - внесенням в орний шар важких металів, що також негативно впливає на навколишнє середовище.

Традиційні мінеральні добрива через значну швидкість розчинення мають невисокий коефіцієнт використання поживних речовин, що призводить, з одного боку, до неефективного використання фінансових ресурсів, а 3 іншого - $\epsilon$ потужним фактором впливу на екологічний стан грунту, водних систем і атмосферного повітря.

Зважаючи на безальтернативність широкого застосування мінеральних добрив, потреба у зниженні техногенного навантаження агропромислового виробництва в Україні набуває вирішального значення. Запропоновані технічні рішення з капсулювання азотних добрив моноамонійфосфатами, полімерними та іншими плівкоутворювачами на сьогодні ще не набули належного промислового застосування та потребують додаткового опрацювання зі спрощення технології їх одержання і визначення фізико-хімічних показників нових видів капсульованих добрив.

Аналіз останніх досліджень і публікацій. Екологотехнологічні аспекти виробництва та застосування гранульованих мінеральних добрив досліджено у працях (Nagursky, 2012; Tymchuk, 2014; Ostroha, 2015). У зазначених роботах особливу увагу приділено фізико-хімічним властивостям капсульованих азотних добрив та їх розчинності у грунтово-водних системах сільськогосподарських угідь (Nagursky, 2012; Chandyba, 2018; Vakal, 2018).

Водночас такі актуальні питання, як визначення ефективних $з$ точки зору екологічної безпечності складових покриття азотних гранул, підтримки лужного або нейтрального балансу грунтового шару при використанні добрив та мінімізації дії на грунт важких елементів, що містяться в фосфатній сировині, ще не набули належного наукового обгрунтування.

Азотні добрива, забезпечуючи потреби вегетативних органів рослин у живленні, мають також істотні недоліки, які пов'язані з істотним накопиченням нітратів у орному шарі, що призводить до забруднення ними сільськогосподарської продукції та водного і повітряного басейнів (Ostroha, 2015). Водночас азотні добрива, зазвичай, підвищують кислотність грунту, що збільшує вміст водорозчинних форм важких металів у ньому та призводить до деградації всього грунтового шару. Відсутність на цей час в агропромисловому виробництві достатньої кількості органічних добрив також не дає змоги організувати комплексне удобрення рослин поживними речовинами, що призводить до розбалансованості живлення та непродуктивних втрат поживних елементів.

Наявність у грунті поряд із поживними елементами водорозчинних форм токсикантів, особливо кадмію i плюмбуму, призводить до засвоєння цього комплексу частково рослинами і переходу по харчовому ланцюгу в організм тварин і людини. Друга частина 3 них забруднює акватичні системи і через питну воду також може потрапити в організм людини (Myslyva, 2011).

Мета роботи - оптимізація хімічного складу фосфатовмісної оболонки та визначення пролонгуючого й екологічного ефектів нового органо-мінерального добрива.

Результати дослідження та їх обговорення. Дослідження 3 визначення кінетики розчинення капсульова- них азотних добрив проводили зі зразками добрив, вироблених у ході раніше проведених досліджень (Guretc, 2018). Важливою характеристикою добрив із покриттям на основі фосфат-глауконітового концентрату $€$ уповільнення часу розчинення поживних речовин, що дає змогу підвищити коефіцієнт використання добрив й отримати значні екологічний та економічний ефекти. На швидкість розчинення азотного ядра гранули й дифузію поживного компонента через оболонку істотно впливає товщина та склад оболонки.

Для визначення рухомості нітратів і амонію по профілю грунту та встановлення впливу нових видів добрив на вимивання поживних речовин із орного шару грунту здійснено лабораторно-модельні дослідження у грунтових колонках. Для дослідів використовували чорнозем опідзолений важкосуглинковий, відібраний на Коротичанському дослідному полі Харківської обл.

Кількість внесених добрив, хімічний склад яких наведено в табл. 1, розраховано за діючою речовиною по азоту, який взято у подвійній дозі $\left(\mathrm{N}_{120}\right)$. Схема досліду: 1) контроль - без добрив; 2) традиційні добрива (амоніачна селітра), 130 мг на колонку; 3) карбамід, 158 мг/колонку; 4) карбамід, покритий суперфосфатом, пластифікатор гумат кальцію, 184 мг/колонку; 5) карбамід, покритий сумішшю суперфосфату й цеоліту, пластифікатор гумат кальцію, 212 мг/колонку; 6) карбамід, покритий сумішшю суперфосфату та цеоліту, пластифікатор гумат кальцію и $50 \%$ розчин карбаміду, 202 мг/колонку.

Табл. 1. Хімічний склад добрив із органо-мінеральним покриттям

\begin{tabular}{|c|c|c|c|c|c|}
\hline \multirow{3}{*}{ Вид добрива } & \multicolumn{5}{|c|}{ Показник } \\
\hline & $\mathrm{N}_{3 \mathrm{ar}}$ & $\mathrm{P}_{2} \mathrm{O}_{5 \text { заг }}$ & $\mathrm{P}_{2} \mathrm{O}_{5 \text { в.p. }}$ & $\mathrm{H}_{2} \mathrm{O}$ & \multirow{2}{*}{$\mathrm{pH}$} \\
\hline & \multicolumn{4}{|c|}{$\%$} & \\
\hline 1. Карбамід & 46,2 & - & - & - & - \\
\hline $\begin{array}{l}\text { 2. Карбамід, покритий су- } \\
\text { перфосфатом, пласти- } \\
\text { фікатор гумат кальцію }\end{array}$ & 24,10 & 6,80 & 3,9 & 1,97 & 2,4 \\
\hline $\begin{array}{l}\text { 3. Карбамід, покритий су- } \\
\text { мішшю суперфосфату й } \\
\text { цеоліту, пластифікатор } \\
\text { гумат кальцію }\end{array}$ & 21,26 & 5,36 & 2,73 & 3,19 & 3,1 \\
\hline $\begin{array}{l}\text { 4. Карбамід, покритий су- } \\
\text { мішшю суперфосфату й } \\
\text { цеоліту, пластифікатор } \\
\text { гумат кальцію і } 50 \text { \% } \\
\text { розчин карбаміду }\end{array}$ & 22,04 & 5,27 & 2,9 & 1,70 & 2,6 \\
\hline
\end{tabular}

Результати аналізів промивних вод, які відбирали й аналізували за стандартними методиками на вміст азоту, $\mathrm{P}_{2} \mathrm{O}_{5}, \mathrm{CaO}$ та $\mathrm{Fe}_{2} \mathrm{O}_{3}$ У кожній промивці, представлено на рис. 1-4.

Згідно 3 дослідженнями, як показано на рис. 1, найбільше вимивався азот традиційного карбаміду; потім карбамід, покритий сумішшю суперфосфату та цеоліту, пластифікатор гумат кальцію і 50 \% розчин карбаміду; менше вимився карбамід, покритий сумішшю суперфосфату та цеоліту, пластифікатор гумат кальцію; а потім карбамід, покритий суперфосфатом, пластифікатор гумат кальцію. Отже, очікування збільшення пролонгації часу розчинення ядра гранули внаслідок збільшення сорбційних властивостей цеоліту, який було введено до складу покриття, не справдились.

Найкращу пролонгуючу властивість показав зразок карбаміду, капсульований суперфосфатом, який одержано 3 Ново-Амвросіївського фосфат-глауконітового концентрату. 


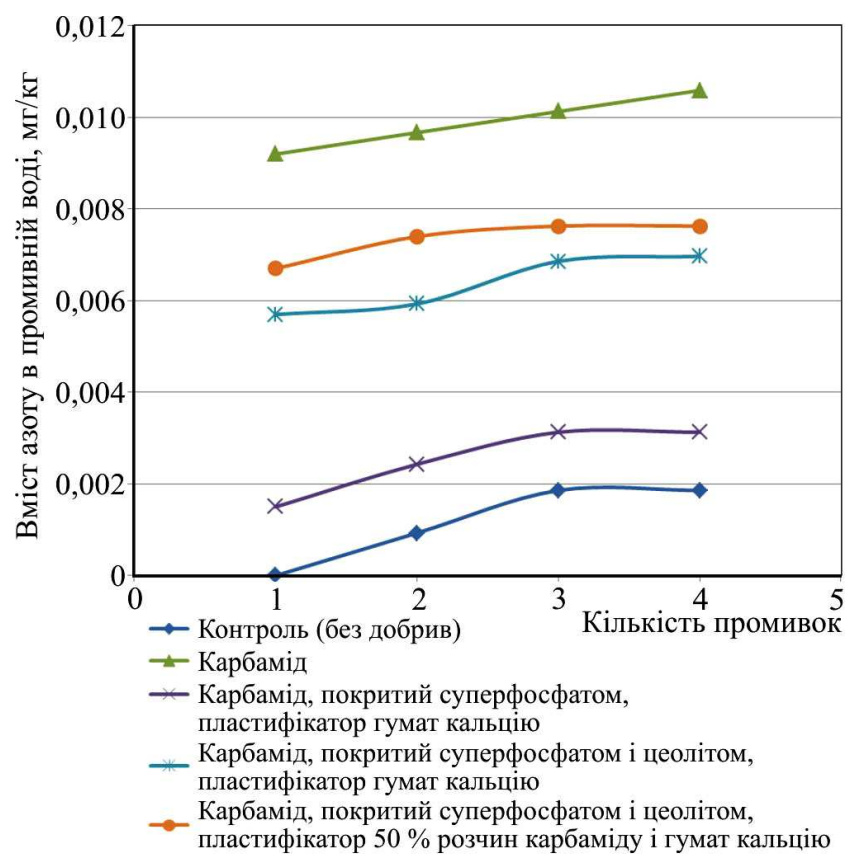

Рис. 1. Залежність втрат азоту від кількості промивок

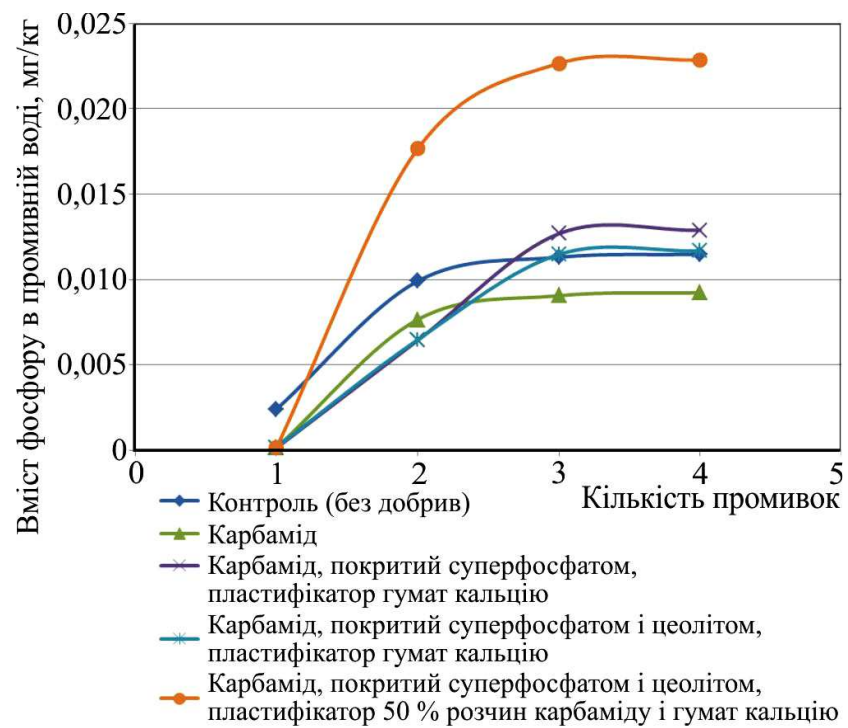

Рис. 2. Залежність втрат $\mathrm{P}_{2} \mathrm{O}_{5}$ від кількості промивок

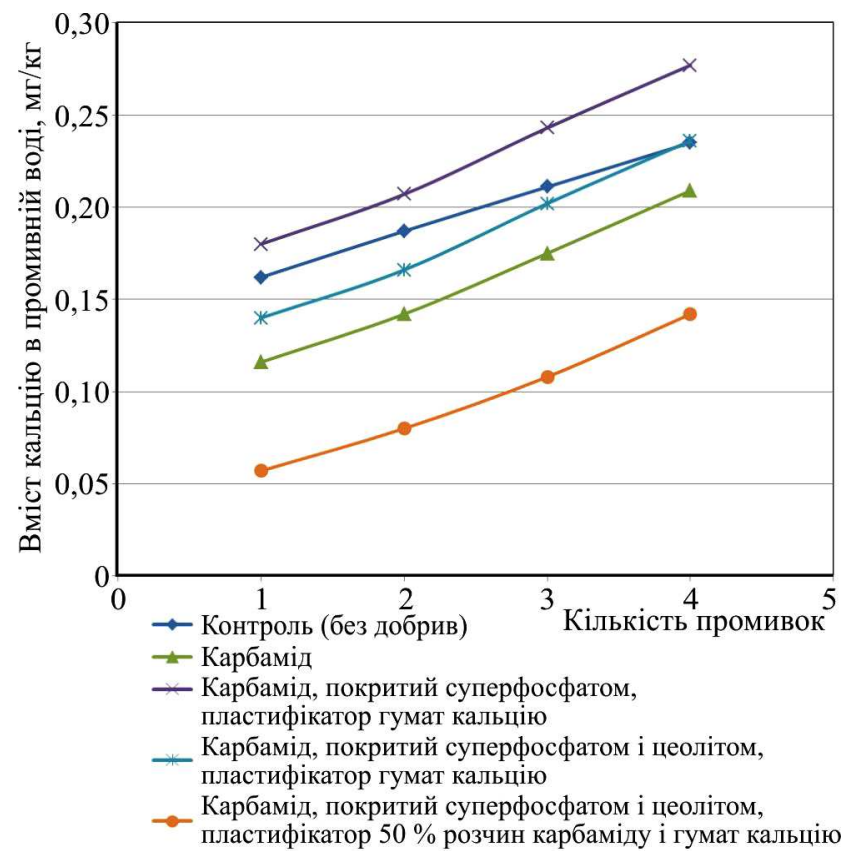

Рис. 3. Залежність втрат $\mathrm{CaO}$ від кількості промивок

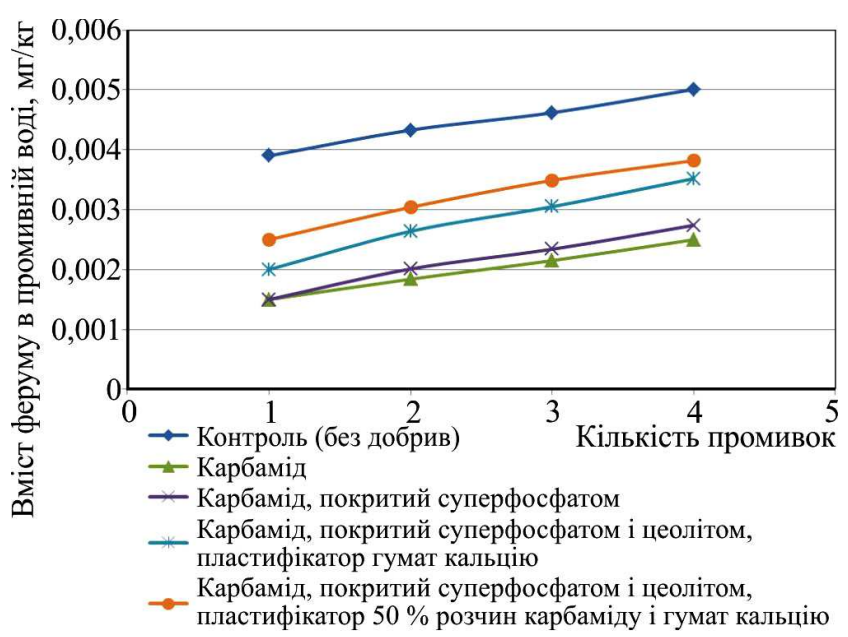

Рис. 4. Залежність втрат $\mathrm{Fe}_{2} \mathrm{O}_{3}$ від кількості промивок

Представлена на рис. 2 залежність вимивання рухомих форм $\mathrm{P}_{2} \mathrm{O}_{5}$ показує, що карбамід, покритий сумішшю суперфосфату та цеоліту, пластифікатор гумат кальцію і $50 \%$ розчин карбаміду, має найшвидший час розчину фосфатовмісної оболонки гранули карбаміду, що впливає на швидке розчинення гранули карбаміду. Покриття карбаміду сумішшю суперфосфату та цеоліту 3 пластифікатором гуматом кальцію та карбамідом, покритий суперфосфатом 3 пластифікатором гуматом кальцію, показали значно менші втрати $\mathrm{P}_{2} \mathrm{O}_{5}$ у ході дослідів, що свідчить про пролонгуючу дію складу фосфатовмісної оболонки.

Як свідчать результати визначення кількості вимитого $\mathrm{CaO}$ (рис. 3), найбільші значення належать зразку карбаміду, покритому суперфосфатом 3 пластифікатором гуматом кальцію. Це дає змогу попередньо передбачити не зниження кислотності грунту при внесенні такого виду добрив. Визначення $\mathrm{pH}$ водного розчину капсульованих добрив, яке наведено в табл. 2, показує, що саме для зразків добрив із максимальним значенням водорозчинного кальцію характерний високий $\mathrm{pH}$.

Табл. 2. Значення рН залежно від складу фосфатовмісної оболонки

\begin{tabular}{|l|c|}
\hline \multicolumn{1}{|c|}{ Склад фосфатовмісної оболонки } & $\begin{array}{c}\text { pH 10 \% } \\
\text { розчину }\end{array}$ \\
\hline Контроль (без добрив) & 6,63 \\
\hline Амоніачна селітра & 5,96 \\
\hline Карбамід & 6,7 \\
\hline $\begin{array}{l}\text { Карбамід, капсульований суперфосфатом, пласти- } \\
\text { фікатор гумат кальцію }\end{array}$ & 6,9 \\
\hline $\begin{array}{l}\text { Карбамід, капсульований сумішшю суперфосфату } \\
\text { й цеоліту, пластифікатор гумат кальцію }\end{array}$ & 6,66 \\
\hline $\begin{array}{l}\text { Карбамід, капсульований сумішшю суперфосфату } \\
\text { й цеоліту, пластифікатор гумат кальцію, покритий } \\
\text { сумішшю суперфосфату й цеоліту, пластіфикатор } \\
\text { гумат кальцію і 50\% розчин карбаміду }\end{array}$ & 6,8 \\
\hline
\end{tabular}

Аналізуючи графік на рис. 3 , також можна зробити висновок щодо позитивної дії гумату кальцію у складі покриття з суперфосфату. Представлені результати досліджень підтверджують дані авторів (Pirogovskaya, 2011; Myslyva, 2011) про ефективність органо-мінеральних композицій.

Залежності на рис. 3 показують, що сорбційні властивості цеоліту у складі фосфатовмісної оболонки у проведених дослідах не проявилися, а їх застосування в процесах капсулювання потребує додаткового експериментального обгрунтування.

Результати досліджень, які представлені на рис. 4, показують, що всі зразки капсульованих фосфатовміс- 
ними оболонками добрив дають змогу зменшити надходження оксидів заліза у грунти. Дані дослідів дають змогу розглядати капсулювання фосфатовмісними органо-мінеральними оболонками як однин 3 варіантів зниження техногенного навантаження на довкілля шляхом блокування шкідливих домішок у грунтах при застосуванні пропонованого виду добрив.

За результатами проведених досліджень можна зробити попередній висновок, що відпрацьовані варіанти складу органо-мінерального покриття на основі фосфат-глауконітового концентрату Ново-Амвросіївського родовища можна розглядати як ефективне пролонговане екологічно безпечне добриво.

Відповідно до методики досліджень, яку викладено вище, визначено кількість рухомих форм кадмію i плюмбуму під час промивок залежно від хімічного складу покриття гранули. Для зниження впливу на рухомі форми полютантів умов синтезу суперфосфату з фосфат-глауконітового концентрату проведено модельні дослідження з капсульованими добривами, де у складі покриття замість амонізованого суперфосфату застосовували ту саму кількість фосфат-глауконітового концентрату Ново-Амросіївського родовища.

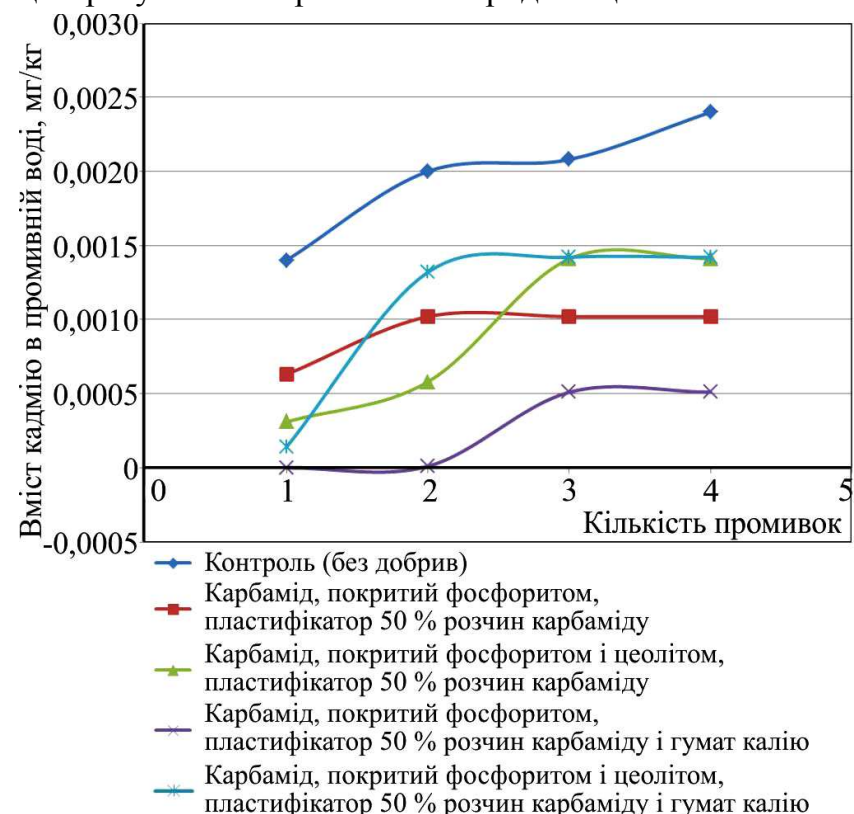

Рис. 5. Залежність виносу водорозчинних сполук кадмію від кількості промивок

Як показано на рис. 5, найбільше вимивались рухомі форми кадмію, порівняно 3 контролем, 3 гранул, що вкриті оболонкою, в якій містився фосфорит і цеоліт, пластифікатором був $50 \%$ розчин карбаміду та гумат калію; менше - карбамід, покритий фосфоритовим концентратом 3 цеолітом, пластифікатор - $50 \%$ розчин карбаміду; а потім карбамід, покритий фосфоритовим концентратом, пластифікатор - 50 \% розчин карбаміду.

Тільки в дослідах, де як добавку було введено до складу покриття гумат калію, без добавки цеоліту, було досягнуто ефект значного зниження вимивання кадмію зі складу добрив. У проведених дослідах очікування зниження вимивання рухомих форм кадмію за рахунок сорбційних властивостей цеоліту, введеного у склад покриття, не справдились.

Результати проведення дослідів із визначення виносу рухомих форм плюмбуму під час промивок у грунтовій колонці представлено на рис. 6.

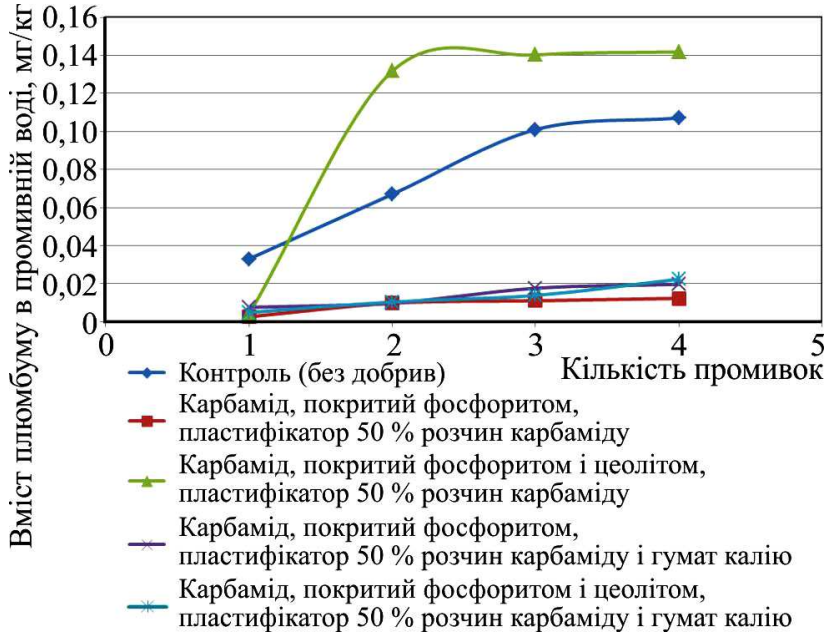

Рис. 6. Залежність виносу водорозчинних сполук плюмбуму від кількості промивок

Представлена на рис. 6 залежність вимивання рухомих форм плюмбуму показує, що карбамід, покритий сумішшю фосфат-глауконітового концентрату та цеоліту 3 пластифікатором $50 \%$ розчином карбаміду, має найшвидший час розчину фосфатовмісної оболонки гранули карбаміду, навіть більший, ніж грунт без добрив. Оболонка, у складі якої $\epsilon$ фосфат-глауконітовий концентрат 3 пластифікатором 50 \% розчином карбаміду, фосфат-глауконітовий концентрат з пластифікатором $50 \%$ розчином карбаміду та гуматом калію, фосфат-глауконітового концентрату та цеоліту з пластифікатором $50 \%$ розчином карбаміду та гуматом калію, покритий суперфосфатом 3 пластифікатором гуматом калію, показали значно менші втрати $\mathrm{P}_{2} \mathrm{O}_{5}$ у ході дослідів, що свідчить про пролонгуючу дію складу фосфатовмісної оболонки.

Результати проведених досліджень показують, що капсулювання азотних добрив фосфатовмісними оболонками дає змогу знизити швидкість вивільнення азотного складника добрива, а також водорозчинних сполук кадмію і плюмбуму. Зважаючи на те, що ці елементи належать до першого класу небезпечності "високо небезпечні", то доцільно розрахувати коефіцієнт небезпеки елемента-забруднювача $\left(K_{н б}\right)$, який визначають як співвідношення між концентрацією полютанта та його ГДК. За нормальних умов коефіцієнт небезпеки має бути меншим або дорівнювати 1.

$$
K_{н \sigma}=C_{i} / \Gamma Д K_{i} \leq 1,
$$

де: $C_{i}$ - концентрація $i$-тої забруднювальної речовини, мг/кг; ГДК - гранично допустима концентрація $i$-тої забруднювальної речовини, мг/кг (Myslyva, 2011).

Для сільськогосподарського виробництва найбільшу небезпеку мають рухомі форми важких металів, оскільки саме вони є легкодоступними для рослин (Myslyva, 2011). Тому під час розрахунку коефіцієнта небезпеки, за результатами експериментальних досліджень, порівнювали рухомі форми кадмію і плюмбуму відносно ГДК їх рухомих форм (табл. 3).

Як свідчать дані табл. 3, коефіцієнт небезпечності 3 кадмію та плюмбуму кожного виду капсульованого добрива значно менше 1. Цей показник свідчить про те, що цей вид добрива не $\epsilon$ пріоритетним забруднювачем

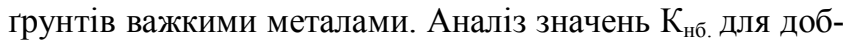
рив 3 різним складом фосфатовмісної оболонки дає змогу зробити висновок про позитивний вплив гумату калію на зниження рухомих форм ВМ під час капсулю- 
вання азотних добрив фосфатами. В окремих випадках відбувається зниження рухомих форм кадмію більше ніж у 4 рази.

Табл. 3. Визначення коефіціснта небезпеки,

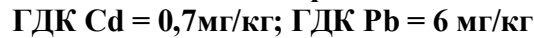

\begin{tabular}{|l|c|c|}
\hline \multicolumn{1}{|c|}{ Дослід } & $K_{\text {нб по Сd }}$ & $K_{\text {нб по Рb }}$ \\
\hline 1. Без добрив & 0,0033 & 0,02 \\
\hline $\begin{array}{l}\text { 2. Карбамід, покритий фосфоритом, } \\
\text { пластифікатор, 50 \% розчин карбамі- } \\
\text { ду }\end{array}$ & 0,0014 & 0,0026 \\
\hline $\begin{array}{l}\text { 3. Карбамід, покритий фосфоритом і це- } \\
\text { олітом, пластифікатор, 50 \% розчин } \\
\text { карбаміду }\end{array}$ & 0,002 & 0,023 \\
\hline $\begin{array}{l}\text { 4. Карбамід, покритий фосфоритом, } \\
\text { пластифікатор, 50 \% розчин карбамі- } \\
\text { ду та гумат кальцію }\end{array}$ & 0,0007 & 0,003 \\
\hline $\begin{array}{l}\text { 5. Карбамід, покритий фосфоритом і це- } \\
\text { олітом, пластифікатор, 50\% розчин } \\
\text { карбаміду та гумат кальцію }\end{array}$ & 0,002 & 0,0036 \\
\hline
\end{tabular}

Висновки. Проаналізувавши отримані експериментальні дані, можна констатувати, що капсулювання азотних добрив фосфатовмісним покриттям на основі фосфат-глауконітового концентрату українського родовища і його похідних істотно знижує швидкість розчинення азотних добрив, яка може коригуватися складом оболонки. Введення до складу оболонки гуматів лужних металів знижує кислотність грунтового шару i вміст рухомих форм важких металів у грунті. Низькі значення коефіцієнта небезпеки для досліджених добрив дає підстави віднести їх до екологічно безпечних.

Для підвищення рівня екологічної безпеки агропромислового виробництва пропонуємо капсулювання азотних добрив фосфатовмісними оболонками на оснодовищ. Навіть інтенсивне удобрення грунтів запропонованими добривами не підвищить рівень забруднення грунтового шару важкими металами, які містяться у складі фосфатовмісних добрив.

\section{Перелік використаних джерел}

Guretc, L. L., Vakal, V. S., Tcapko, Iu. L., \& Vakal, S. V. (2018). Evaluation of the environmental effect when using encapsulated nitrogen fertilizers. Ser. Rozrobka ekolohichno bezpechnykh tekhnolohii, protsesiv i ustatkuvannia. Ekolohichna bezpeka, 1(25), 61. [In Russian].

Lvovich, I. Ya., Preobrazhenskiy, A. P., Tolbatov V. A., et al. (2018). The scientific environment of modern man, (pp. 147-148). Odessa: Kuprienko SV. [In Russian].

Myslyva, T. M., Nadtochii, P. P., Herasymchuk, L. O., et al. (2011). Agricultural production in the private sector in conditions of increased anthropogenic environmental impact. Zhytomyr, $50 \mathrm{p}$. [In Ukrainian].

Nagursky, O. A. (2012). Patterns of the encapsulation of substances in the state of pseudoriginization and their diffuse release. Lviv: Lviv Polytechnic Publishing, 188 p. [In Ukrainian].

Ostroha, R. O., Yukhymenko, M. P., Vakal, V. S., \& Mykhailovskyi, Ya. E. (2015). Capsulated organic-mineral fertilizers of prolonged action. The process of obtaining. Khimichna promyslovist Ukrainy, 1, 40-44. [In Ukrainian].

Pirogovskaya, G. V. (2000). Slow acting fertilizers. Minsk: Selhoznauka, 291 p. [In Russian].

Tymchuk, I. S., \& Malevanyi, M. S. (2014). Fertilizer encapsulationa way to reduce pollution and increase yields. Ustoichivoe razvitie, 20, 109-113. Varna. [In Russian].

Vakal, S. V., \& Vakal, V. S. (2018). Alternative sources of phosphorus and potassium. Agroindustriia, 10, 38-48. [In Russian].

\section{L. Gurets ${ }^{1}$, Yu. L. Tsapko', M. S. Malovanyy3, V. S. Vakal ${ }^{1}$
${ }_{I}^{3}$ Sumy State University, Sumy, Ukraine \\ ${ }^{2}$ National Scientific Center "Institute for Soil Science and Agrochemistry named after O. N. Sokolovsky", Kharkiv, Ukraine \\ 'Sumy State University, Sumy, Ukraine
${ }_{3}^{3}$ Lviv Polytechnic National University, Lviv, Ukraine}

ві фосфат-глауконітових концентратів українських роFERTILIZERS DISSOLUTION

The presented material contains the results of research on the effect of encapsulation of nitrogen fertilizers with phosphate-containing shells on the nature of the granules nitrogen component dissolution and soil contamination by heavy metals that are in phosphate raw materials. During the research, the reduction of the technogenic load on the environment was determined while reducing the rate of dissolution of nitrogen mineral fertilizers by encapsulating them with phosphates. It was established that the inclusion of phosphate-containing coatings in various ratios of sorbents and humates allows changing the prolonging effect of organo-mineral fertilizers. The data of experimental studies on the kinetics of nitrogen fertilization, encapsulated by shells based on domestic phosphate concentrates, are given, the loss of nutrient elements from the granules is determined, and the influence of the phosphate-containing shell components on the migration into the soil of water-soluble pollutants such as iron, cadmium and plumbum oxides is estimated. The significant role of such additives to shell phosphates as zeolite and alkali metal humates is noted. Laboratory studies have shown that the use of a shell based on ammoniated superphosphate and powdered phosphate-glauconite concentrate from the Novo-Amvrosiivskyi field leads to a significant decrease in the rate of dissolution of the nitrogen component of the encapsulated granule. It has been found that the binding of heavy metals to insoluble complexes is positively affected by the intensity of moisture and the properties of modified fertilizers. Analysis of the experimental data showed the effectiveness of introducing into the shell of a zeolite only to slow down the leaching rate of soluble forms of calcium, and increased the rate of leaching for nitrogen and phosphorus. It was determined that the decrease in acidity of soil complexes with the introduction of alkaline metal humates into the phosphate-containing shell reduces the content of water-soluble forms of heavy metals in the arable layer and improves the environmental safety of agricultural production. The calculations of the encapsulated fertilizer hazard factor allow us to conclude that this type of fertilizer is not a priority soil pollutant with heavy metals.

Keywords: carbamide; ammonium nitrate; encapsulation; ammoniated superphosphate; phosphate-glauconite concentrate; heavy metals. 